\title{
Pewarisan Nilai-Nilai Kearifan Lokal Kalosara dalam Pembelajaran Sejarah Untuk Membangun Karakter Siswa
}

\author{
Rispan $^{1,}$ Ajat Sudrajat ${ }^{2}$ \\ ${ }^{1}$ Afiliasi (Program Pascasarjana Universitas Negeri Yogyakarta, Jurusan Pendidikan Sejarah, \\ Program Pascasarjana, Universitas Negeri Yogyakarta, Jalan Colombo No. 1 Sleman 43221, \\ Indonesia. \\ Email: rispan.2017@student.uny.ac.id
}

Received 01 September 2019; Received in revised form 03 December 2019; Accepted 28 February 2020

\begin{abstract}
Abstrak
Penelitian ini bertujuan untuk mengkaji nilai-nilai yang terkandung dalam kearifan lokal kalosara dan akan diintegrasikan kedalam pembelajaran sejarah guna membangun karakter peserta didik. Fokus penelitian ini adalah proses pewarisan nilai-nilai kearifan lokal kalosara terhadap peserta didik. Penelitian ini menggunakan metode kualitatif dengan pendekatan etnografi. Hasil penelitian menunjukan bahwa: nilai-nilai kearifan lokal kalosara yang dapat diaktualisasikan dan diinternalisasikan dalam pembelajaran sejarah antara lain: pertama, nilai kepemimpinan yang berintikan persatuan dan kesatuan (medulu mepoko'aso), keserasian dan keharmonisan, kesucian dan keadilan (ate pute penao moroha), nilai keamanan, kedamaian, keadilan dan kesejahteraan (morini mbu'umbundi monapa mbu'undawaro), kedua, budaya malu (kohanu), ketiga, budaya gotong royong (samaturu), dan keempat, budaya sopan santun(meiro'u) yang meliputi saling hormat-menghormati (mombekapona-pona'ako), dan saling kasih-mengasihi (mombekamei-meiri'ako). Pewarisan nilai-nilai kearifan lokal kalosara sangat penting, selain menjadikan pembelajaran sejarah semakin menarik dan bermakna, juga dapat berfungsi sebagai alat bagi penguatan karakter anak didik untuk mempersiapkan diri dalam menghadapi tantangan masa kini dan masa yang akan datang, sehingga peserta didik memiliki pengetahuan moral, perasaan moral, dan tindakan moral dalam memahami nilai-nilai luhur yang terdapat dalam kebudayaannya. Pewarisan nilai-nilai kearifan lokal kalosara dapat tercapai dengan efektif apabila ada kerjasama antara lingkungan keluarga, masyarakat, dan Sekolah dalam menginternalisasikan nilai budaya tersebut sebagai bagian sumber belajar bagi pembelajaran sejarah di Sekolah. Kata Kunci: Pewarisan Nilai, Kalosara, Pembelajaran Sejarah
\end{abstract}

\begin{abstract}
This study aims to examine the values contained in kalosara local wisdom and will be integrated into historical learning in order to build the character of students. The focus of this research is the process of inheriting the values of Kalosara local wisdom towards students. This study uses a qualitative method with an ethnographic approach. The results showed that: Kalosara local wisdom values that can be actualized and internalized in historical learning include: first, leadership values that are unified and united (medulu mepoko'aso), harmony and harmony, holiness and justice (athe pute penao moroha) ), the value of security, peace, justice and welfare (morini mbu'umbundi monapa mbu'undawaro), second, the culture of shame (kohanu), third, the culture of mutual cooperation (samaturu), and fourth, the culture of courtesy (meiro'u) which include mutual respect (mombekapona-pona'ako), and mutual love (mombekamei-meiriako). Inheritance of Kalosara values of local wisdom is very important, in addition to making history learning more interesting and meaningful, it can also function as a tool for strengthening the character of students to prepare themselves to face the challenges of the present and the future, so that students have moral knowledge, moral feelings, and moral actions in understanding the noble values found in their culture. Inheritance of Kalosara values of local wisdom can be achieved effectively if there is cooperation between the family, community and school environment in internalizing the cultural values as part of learning resources for learning history in the School.
\end{abstract}

Keywords: Inheritance, Kalosara, Learning History 
PENDAHULUAN

Fenomena sosial yang terjadi pada kaum muda antara lain tergerusnya jati diri nasional dan meningkatnya jati diri baru bentukan global. Akibat dari pergeseran nilai tersebut muncul, seperti melunturnya sikap sopan santun, saling menghargai, saling tolong menolong, dan sebagainya. Jika permasalahan ini dibiarkan, akan berakibat melemahnya budaya ini.

Umumnya orang sependapat bahwa situasi dan kondisi kehidupan bangsa Indonesia sedang carut marut dan sangat memprihatinkan di hampir semua sendi-sendi kehidupan. Salah satu diantara banyak penyebab munculnya fenomena diatas adalah kurangnya kesadaran sejarah dalam membentuk generasi bangsa Indonesia.

Akar masalahnya dapat di cari pada cara pengajaran sejarah di sekolahsekolah yang tidak komprehensif, sehingga membuat peserta didik kurang memiliki kesadaran akan sejarah. Pemahaman mereka akan segala sesuatu menjadi berkurang dalam memetik nilai yang terkandung didalamnya.

Masalah urgen yang seringkali terabaikan dalam pembelajaran sejarah Indonesia, adalah minimnya pembahasan materi sejarah lokal atau peristiwa lokal. Guru sejarah seringkali terpaku pada bahan ajar yang tertuang dalam buku paket, sehingga jarang memberikan materi pengayaan sejarah Indonesia, khususnya berbasis peristiwa lokal, dengan dalih mengejar target kurikulum. Namun tidak dipungkiri bahwa banyak guru sejarah yang kesulitan dalam mengembangkan materi peristiwa lokal dalam pembelajaran sejarah Indonesia. Salah satu penyebabnya ialah minimnya referensi tentang peristiwa-peristiwa lokal tersebut.

Pembelajaran sejarah yang berlangsung selama ini belum mengintegrasikan nilai-nilai budaya, sehingga salah satu strategi dalam mengintegrasikan nilai budaya tersebut adalah melalui pembelajaran di sekolah. Dalam kurikulum 2013 dengan pendekatan saintifik memungkinkan strategi tersebut dapat dilaksanakan. Proses pewarisan nilai ini penting, untuk membangun kepribadian dan mempersiapkan diri dalam menghadapitantangan masa kini dan yang akan datang.

Warisan budaya dan kearifan lokal, menjadi bagian penting dalam menumbuhkan dan membangun jati diri. Budaya memberikan kontribusi besar dalam membentuk karakter bangsa yang tergerus oleh pengaruh global. Dari sudut pandang tersebut bangsa Indonesia sesungguhnya memiliki potensi sumber daya atau keunggulan kompetitif karena dikaruniai keanekaragaman budaya . kondisi tersebut diperkaya dengan keberadaan sejumlah komunitas yang dikenal dengan sebutan komunitas adat. 
HISTORIA: Jurnal Program Studi Pendidikan Sejarah Volume 8 (1) 2020

ISSN 2337-4713 (E-ISSN 2442-8728)

Penghayatan dan pengkajian budaya yang minim selama ini, berdampak langsung terhadap rendahnya pemahaman generasi akan kekayaan budaya daerah. Telah disadari banyak pihak bahwa salah satu prinsip dalam menghadapi polarisasi adalah berpola pada budaya. Dalam era modern diperlukan pemahaman akan pentingnya budaya dalam pengembangan sumber daya manusia.

Proses pewarisan nilai kearifan lokal terhadap peserta didik, adalah melalui pendidikan, karena pada dasarnya pendidikan mengandung sesuatu hal yang sangat komprehensif, serta tujuan pendidikan tidak hanya mencerdaskan anak secara intelektualitas akan tetapi lebih pada membangun secara utuh kepribadian dan karakternya.

Masyarakat Tolaki mendiami Jazirah Tenggara Pulau Sulawesi antara lain: Kota Kendari, Konawe, Konawe Utara, Konawe Selatan, dan Kolaka. Masyarakat tersebut memiliki sejumlah budaya dan kearifan lokal yang berlangsung secara turun temurun dan masih eksis hingga saat ini.

Salah satu nilai budaya atau kearifan lokal etnik Tolaki ialah kalosara yang selanjutnya disebut kalo. Dalam kehidupan etnik Tolaki menempatkan kalo sebagai suatu yang sakral, selain berfungsi sebagai lambang pemersatu juga berfungsi sebagai alat penyelesaian berbagai masalah dalam kehidupan bermasyarakat, sehingga menjadikan kalo sebagai fokus sekaligus pusat kebudayaan etnik Tolaki di Sulawesi Tenggara.

Pewarisan nilai-nilai kearifan lokal kalosara sangat penting apabila diintegrasikan dan diinternalisasikan dalam pembelajaran sejarah, sebagai upaya untuk menumbuhkan kesadaran peserta didik akan nilai sejarah dan budayanya yang pada gilirannya akan mengantarkan dirinya menjadi manusia arif dan bijaksana dan mampu menyelesaikan masalah-masalah sosial yang terjadi dalam lingkungan sekitarnya. Sebagaimana tujuan dari pembelajaran sejarah adalah menjadikan manusia bijaksana dan memiliki kesadaran sejarah dan kesadaran budaya. Berdasarkan pemikiran tersebut maka perlu ada kajian mengenai pewarisan nilai-nilai kearifan lokal kalosara dalam pembelajaran sejarah untuk membangun karakter siswa.

\section{METODE}

Penelitian terhadap pewarisan nilai-nilai kearifan lokal kalosaradalam pembelajaran sejarah, ini menggunakan metode kualitatif dengan pendekatan etnografi. Hal tersebut didasari oleh masalah yang diteliti bersifat deskriftif kualitatifyang membutuhkan observasi, wawancara, mengkaji dokumen, menguji keabsahan data melalui tahapan triangulasi, dalam mengungkap kebermaknaan secara interpretatif sebagai jawaban dalam pemecahan masalah penelitian. Penggunaan 
pendekatan etnografi pada penelitian ini disebabkan karena fokus penelitian yang dilakukan adalah mendeskripsikan dan memberi eksplanasi secara detil mengenai nilai-nilai kearifan kalosara dan selanjutnya akan direkonstruksi berdasarkan partisipasi secara alamiah.

\section{HASIL DAN PEMBAHASAN}

Suku Tolaki adalah sekelompok orang yang sejak lama mendiami Jazirah Tenggara Pulau Sulawesi yang terdiri dari beberapa wilayah antara lain. Kota Kendari, Konawe, Konawe Utara, Konawe Selatan, dan Kolaka. Keberadaan masyarakat Tolaki ini masih memegang apa yang menjadi warisan dari para leluhurnya secara turun temurun dan masih menunjukan eksistensinya hingga saat ini.

Hafid (2013:2) mengemukakan bahwa persebaran etnik Tolaki ini membawa sejumlah pranata-pranata sosial, ekonomi, politik, dan tata nilai. Sumber nilai dalam etnik Tolaki disebut kalosara yang selanjutnya disebut kalo. Kalosara hadir dalam kehidupan orang Tolaki bertujuan untuk menciptakan masyarakat yang berbudi luhur serta untuk menjaga ketentraman dan kesejahteraan bersama dalam sektor kehidupan. Masyarakat Tolaki baik yang bermukim di pedesaan sebagai petani tradisional maupun yang bermukim diperkotaan sebagai pegawai negeri atau pengusaha sampai saat ini masih menempatkan kalo sebagai suatu yang sakral (Tarimana, 1993: 283).

Bagi masyarakat Tolaki, kalo merupakan suatu pedoman yang mempengaruhi kehidupan masyarakat. Pada dasarnya masyarakat Tolaki memiliki kemampuan beradaptasi, berinteraksi, dan menjalin hubungan yang harmonis dengan lingkungannya, baik lingkungan sosial maupun lingkungan alam. Kearifan lokal kalosara pada masyarakat Tolaki merupakan eksistensi keberdayaan dalam mendayagunakan potensi yang mengacu pada nilai-nilai budaya dan terefleksikan dalam wujud perilaku pada berbagai sektor kehidupan, sehingga menjadikan kalo sebagai pedoman dan pengontrol perilaku dalam menciptakan lingkungan sosial yang harmonis.

Tarimana (1993:283) mempertegas bahwa kalo memiliki empat fungsi antara lain: (1) Kalo sebagai ide dalam kebudayaan dan sebagai kenyataan dalam kehidupan etnik Tolaki, (2) kalo sebagai fokus dan pengintegrasi unsur-unsur kebudayaan Tolaki, (3) kalo sebagai pedoman hidup untuk terciptanya ketertiban sosial dan moral dalam kehidupan etnik Tolaki, dan (4) kalo sebagai pemersatu untuk pertentanganpertentangan konseptual dan sosial dalam kebudayaan dan kehidupan etnik Tolaki.

Kalo Sebagai Ide Dalam Kebudayaan dan Sebagai Kenyataan dalam Kehidupan Etnik Tolaki 
HISTORIA: Jurnal Program Studi Pendidikan Sejarah Volume 8 (1) 2020

ISSN 2337-4713 (E-ISSN 2442-8728)

Sebagaimana yang diungkapkan Koentjaraningrat (1984: 9-13) bahwa wujud ideal dari suatu kebudayaan adalah salah satu dari tiga wujud kebudayaan. Dua wujud lainnya adalah wujud kelakuan dan wujud fisik. Wujud ideal dari suatu kebudayaan adalah adat, atau lebih lengkapnya disebut adat tata kelakuan, karena adat berfungsi sebagai pengatur kelakuan. Adat dapat dibagi dalam empat tingkatan antara lain. tingkat nilai budaya, tingkat norma-norma, tingkat hukum, dan tingkat aturan khusus. Maka kalo dalam tinjauan sebagai adat memiliki empat tingkatan antara lain sebagai berikut.

\section{Tingkat Nilai Budaya}

Tingkat nilai budaya merupakan sistem nilai budaya yang berfungsi mewujudkan ide-ide dan mengkonsepsikan hal-hal paling bernilai bagi masyarakat Tolaki dalam hidupannya dikenal dengan sebutan medulu mepoko'aso (persatuan dan kesatuan), ate pute penao moroha (kesucian dan keadilan), dan morini mbu'mbundi monapa mbu'undawaro (kemakmuran dan kesejahteraan).

a) Ide Medulu Mepoko'aso (persatuan dan kesatuan)

Ide medulu mepoko'aso (persatuan dan kesatuan) diwujudkan dalam apa yang disebut mete'alo-alo (bantu-membantu) antara keluarga inti atau antara kerabat luas dengan kerabat luas dalam hal mendirikan rumah, sumbangan berupa makanan dan minuman, pada acara-acara, terutama dalam acara perkawinan, dan acara kematian.

b) Ide Ate Pute Penao Moroha (Kesucian dan Keadilan)

Ide kesucian diwijudkan dalam rangkaian aktifitas lingkaran hidup seseorang, seperti permandian bayi pertama, pemotongan rambut bayi, penyunatan, pembayatan calon pengantin, mandi masal untuk memasuki bulan puasa, dan permandian mayat. Sedangkan ide keadilan diwujudkan dalam pengambilan keputusan terhadap pembagian warisan kepada anak-anak yang dilakukan orang tua dalam pengambilan keputusan peradilan adat yang dilakukan oleh hakim adat.

c) Ide Morini Mbu'umbundi Monapa Mbu'undawaro (Kemakmuran dan Kesejahteraan)

$$
\text { Ide morini mbu'mbundi }
$$
(kemakmuran) diwujudkan dalam usaha mereka untuk merealisasikan dengan apa yang disebut mondaweako (jutaan ikat padi), tepohiu o'epe (bertebaran bidang kebun sagu). Sejalan dengan itu, Melamba (2014: 236) menyatakan bahwa tanaman sagu memiliki kedudukan yang sangat penting bagi kehidupan masyarakat Tolaki karena pada masa lalu dijadikan sebagai harta warisan (hapo-hapo/tiari) dan sebagai simbol bagi kesejahteraan masyarakat Tolaki, kiniku banggona (kerbau berombongan), lua-luano wawo raha (kebun kelapa yang luas). 
d) Ide Monapa Mbu'undawaro (Kesejahteraan)

Ide Monapa Mbu'undawaro (Kesejahteraan) diwujudkan dengan apa yang disebut mombekapona-pona'ako (saling hormat menghormati), mombekamei-meiri'ako (saling kasih mengasihi), ndudu karandu (suasana ketenangan batin yang diliputi dengan alunan bunyi gong yang merdu di tengah malam), dan tumotapa rarai (suasana kegembiraan yang diliputi dengan suara hura-hura, tawa dan tepuk tangan yang meriah) (Tarimana, 1993:285).

\section{Tingkat Norma-Norma}

Pada tingkat norma-norma merupakan nilai-nilai budaya yang berfungsi mengaitkan peranan-peranan tertentu dari orang Tolaki dalam masyarakatnya. Kalo berfungsi sebagai pedoman bagi tingkah laku masyarakat Tolaki dalam kehidupannya baik dalam kehidupan keluarga, sosial, politik, dan keagamaan.

\section{Tingkat Sistem Hukum}

Pada tingkat sistem hukum merupakan hukum adat orang Tolaki yang berfungsi mengatur bermacam-macam sektor kehidupan orang Tolaki. Kalo sebagai hukum adat tampak pada gejala dimana kalo berfungsi sebagai alat komunikasi antar keluarga, antar golongan, bahkan sebagai alat yang dipakai dalam penyelenggaraan perkawinan, juga dipakai untuk menyumpa seorang raja, selain itu digunakan dalam upacara tolak bala dan meminta berkah. Penggunaan kalo dalam beberapa sektor kehidupan orang Tolaki tersebut merupakan ketentuan-ketentuan hukum adat yang harus ditaati. Pelanggaran terhadap segala aturan adat akan mendapatkan sanksi baik berupa sanksi batin maupun sanksi fisik (Tarimana, 1993: 287).

\section{Tingkat Aturan Khusus}

Pada tingkat aturan khusus merupakan aturan-aturan khusus yang mengatur aktifitas-aktifitas yang amat jelas dan terbatas ruang lingkupnya dalam kehidupan masyarakat Tolaki. Kalo sebagai aturan-aturan khusus tertuang dalam apa yang disebut merou (aturan khusus dalam berbahasa yang menunjukan sopan santun), atora (aturan khusus dalam komunikasi sosial), o wua (aturan khusus dalam bercocok tanam pada umumnya), $o$ lawi (aturan khusus dalam bercocok tanam padi khususnya), o sapa (aturan khusus dalam berburu, beternak, dan menangkap ikan), dan mepori (aturan khusus dalam membuat dan memakai peralatan).

Kalo Sebagai Fokus dan Pengintegrasi Unsur-Unsur Kebudayaan Tolaki

Kalo sebagai fokus dan pengintegrasi unsur-unsur kebudayaan Tolaki bahwa kalo ada hubungannya dengan bahasa sebagai lambang komunikasi, demikian dengan unsur-unsur ekonomi melalui fungsi kalo sebagai penjaga tanaman dan pusat ladang padi, 
HISTORIA: Jurnal Program Studi Pendidikan Sejarah Volume 8 (1) 2020

ISSN 2337-4713 (E-ISSN 2442-8728)

dan melalui makna simbolik kalo sebagai asas ditribusi barang-barang ekonomi. Kalo juga ada hubungannya dengan sistem teknologi melalui bentuknya sebagai model dari teknik mengikat dan bentuk alat-peralatan, demikian juga ada hubungannya dengan organisasi sosial melalui makna simboliknya sebagai asas organisasi tradisional, asas organisasi kerajaan, dan sebagai asas politik dan pemerintahan.

Tarimana (2013:291) menguraikan bahwa makna simbolik dari unsur-unsur upacara terintegrasi didalam makna simbolik dari kalo. Ide medulu mepoko'aso (persatuan dan kesatuan) tercermin di dalam makna simbolik dari lingkaran rotan, demikian juga ide-ide ate pute penao moroha (keikhlasan dan kesucian) tercermin didalam makna simbolik dari kain putih, dan ide-ide kemakmuran dan kesejahteraan tercermin didalam makna simbolik dari wadah anyaman dimana lingkaran rotan diletahkan.

Dengan peranan kalo dalam fungsinya sebagai pengintegrasi unsurunsur kebudayaan Tolaki, baik dalam hungannya dengan beberapa sub unsur dari tiap unsur kebudayaan Tolaki maupun fungsinya sebagai unsur utama dalam upacara, maka kalo sangat erat kaitannya dengan aktifitas orang Tolaki dalam memenuhi dan memuaskan banyak kebutuhan dasar.
Kalo Sebagai Pedoman Hidup Untuk Terciptanya Ketertiban Sosial Dan Moral Orang Tolaki

Kalo sebagai pedoman hidup untuk terciptanya ketertiban sosial dan moral orang Tolaki, menggunakan ajaran-ajaran kalo sebagai pedoman hidup, hal tersebut tampak dalam usaha memulihkan suasana kelaparan karena panen tidak jadi, suasana kecelakaan karena bencana alam, suasana kematian yang disebabkan oleh wabah penyakit, suasana penganiayaan karena permusuhan, dan suasana keretakan dan kesalapahaman bak antar individu, keluarga, maupun antar golongan, sehingga orang Tolaki menganggap bahwa timbulnya suasana tidak baik disebabkan oleh manusia yang telah melanggar adat dan norma-norma agama, sehingga untuk memulihkan suasana tersebut, maka diadakan upacara yang disebut mosehe wonua (upacara besar dan diikuti oleh sebagian besar masyarakat Tolaki).

\section{Kalo Sebagai Pemersatu Dalam} Pertentangan Konseptual Dan Sosial Kebudayaan Tolaki

Kalo sebagai pemersatu dalam pertentangan konseptual dan sosial kebudayaan Tolaki, tercermin pada peranan kalo dalam menyelesaikan berbagai masalah-masalah yang timbul dalam kehidupan orang Tolaki antara lain.

Pertama, kalosara digunakan dalam mendamaikan serta mempersatukan antara golongan 
bagsawan dan golongan budak disebut kalosara mbutobu, yakni kalo yang digunakan untuk menghadap kepada putobu (kepala wilayah) agar kepala wilayah turun tangan dalam memulihkan perselisihan tersebut.

Kedua, kalosara digunakan dalam mendamaikan dan mempersatukan antara golongan pemerintah dan golongan rakyat disebut sara mokole, yakni kalosara yang digunakan untuk menghadap mokole (raja) agar raja turun tangan dalam memulihkan perselisihan tersebut.

Ketiga, kalosaradigunakan untuk mendamaikan atau mempersatukan dua pihak keluarga yang berselisih karena masalah kawin lari disebut kalosara sokei yakni kalo yang berfungsi untuk membentengi diri dari pihak keluarga yang melarikan gadis dari serangan pihak keluarga yang anak gadisnya dilarikan.

Keempat, kalosara digunakan untuk mendamaikan atau mempersatukan orang dengan seorang yang berselisih disebut kalosara mekindoroa, yakni kalosara yang berfungsi untuk menyelamatkan hidup seseorang yang berselisih karena keduanya saling mengancam untuk membunuh lawannya.

Agar setiap orang terhindar dari pelanggaran dan menyebabkan kehadiran kalo, maka dikembangkanlah kata-kata falsafah yang dapat memberikan sugesti kepada anggota masyarakat pada umumnya dan kehidupan orang Tolaki pada khususnya untuk bertingkah laku dengan baik. keseluruhan aturan kalo memiliki nilai filosofi yang dikenal dengan ungkapan Inae Kona Sara le Pinesara, Inae Liasara, le Pinekasara. Falsafah tersebut mengandung arti bahwa barang siapa yang menghormati adat, maka akan diperlakukan secara baik, dan barang siapa yang tidak menghormati adat, maka akan diperlakukan secara kasar (dihukum).

Mazi (2004: 5) menegaskan bahwa ungkapan memiliki makna yang sangat mendalam dalam kehidupan masyarakat. Setiap individu diharapkan untuk hidup dan bertingkah laku sesuai dengan norma atau adat istiadat yang berlaku dalam masyarakat. Seseorang akan mendapatkan penilaian yang baik apabila sikap dan tingkah lakunya sesuai dengan normanorma yang berlaku. Sebaliknya seseorang akan mendapatkan penilaian yang buruk apabila sikap dan tingkah lakunya tidak sesuai dengan norma-norma yang berlaku.

Sesuai dengan fokus penelitian mengenai pewarisan nilai-nilai kearifan lokal kalosara terhadap peserta didik, maka dalam konteks pembelajaran, nilainilai kearifan lokal kalosara yang dapat diintegrasikan dan diinternalisasikan dalam pembelajaran sejarah untuk membangun karakter peserta didik adalah sebagai berikut:

\section{Pertama, nilai}

kepemimpinan,secara historis, lembaga adat kalosara merupakan landasan dasar dari keseluruhan sistem sosial budaya 
HISTORIA: Jurnal Program Studi Pendidikan Sejarah Volume 8 (1) 2020

ISSN 2337-4713 (E-ISSN 2442-8728)

masyarakat Tolaki, termasuk kepemimpinan, kaidah-kaidah hidup bermasyarakat, sistem norma-norma, sistem hukum dan aturan-aturan lainnya.

$$
\text { Basrin Melamba (2013:83) }
$$

menguraikanbahwa konsep kepemimpinan dalam kelompok etnik Tolakitelah berlangsung sejak ratusan tahun yang lalu. Hal tersebut dapat dilihat dari tatanan sosial dan politik yang perlahan membentuk unit-unit kesatuan berupa tempat tinggal atau lingkungan sosial yang disebut o'napo atau o'kambo (kampung), dan menunjuk salah seorang pemimpin yang dikenal dengan sebutan To'ono motuo (orang yang dituakan) dan dibantu oleh beberapa perangkat dalam rangka membina tatanan kehidupan bermasyarakat. Seiring dengan pertambahan penduduk, pemukiman disebut tobu yang di kepalai oleh Pu'u tobu, dan wilayah tobu ini merupakan gabungan dari beberapa o'napo. Terbentuknya wilayah tobu membentuk kesatuan yang lebih besar yaitu wilayah wonua (negeri) yang dipimpin oleh mokole (raja).

Dalam kehidupan sosial budaya Orang Tolaki sehari-hari secara umum baik merupakan rakyat biasa, sebagai seorang tokoh formal maupun nonformal, nilai-nilai kepemimpinan yang terkandung dalam lembaga adat kalosara berintikan dengan sebutanmedulu mepokoaso(persatuan dan kesatuan), ate pute penao moroh (kesucian dan keadilan),morini mbu'umbundi monapa mbu'undawaro(kemakmuran dan kesejahteraan), keserasian, keharmonisan, keamanan dan kedamaian. Lembaga adat kalosara juga menjadi landasan kultural bagi setiap individu dalam menciptakan suasana kehidupan bersama yang aman dan damai serta dalam menegakkan aturan baik berupa hukum adat maupun hukum negara (Tawulo 1991). Oleh karena itu, bagi orang Tolaki menghargai, mengkeramatkan, mematuhi, melaksanakan mensucikan, kalo berarti mentaati ajaran-ajaran nenek moyang mereka yang berlangsung secara turun temurun. Apabila mereka berbuat sebaliknya, diyakini akan mendatangkan bala atau durhaka (Tarimana, 1993; Su’ud, 1992).

Kedua, budaya malu (kohanu). Bagi masyarakat Tolaki budaya malu (kohanu) merupakan sistem pertahanan moral bagi diri sendiri. Hal tersebut tercermin ketika seseorang dikatakan malas bekerja, maka selanjutnya mereka menerapkan budaya malu (kohanu) dengan cara lebih tekun dan rajin dalam bekerja, sehingga sebutan sebagai pemalas akan hilang dari dirinya dan berganti dengan sebutan pekerja keras yang rajin dan tekun (Hafid, 2013:7).

Sadar atau tidak, secara tidak langsung budaya malu (kohanu) sangat mempengaruhi kehidupan orang Tolaki dalam berbagai sektor kehidupan, baik 
sosial, ekonomi, politik, pendidikan, maupun keagamaan.

Ketiga, budaya gotong royong (samaturu). Bagi masyarakat Tolakibudaya gotong royong (samaturu) merupakan salah satu budaya yang mengutamakan hidup untuk selalu menjalin persatuan, suka menolong orang lain yang sedang membutuhkan pertolongan dengan senang hati. Ini juga merupakan wujud gotong royong yang menjadi pandangan hidup utama orang Tolaki.

Dalam tatanan jenisnya, budaya gotong royong (samaturu) terbagi atas dua jenis yaitu gotong royong hakiki, dan gotong royong biasa. Perwujudan gotong royong hakiki dilakukan pada saat upacara perkawinan, kematian, pergantian tahun pertanian, pembukaan lahan perkebunan, penanaman dan pemanenan padi, pelantikan raja, dan penyambutan para pejabat pemerintah, syukuran dan upacara tolak bala. Sedangkan untuk perwujudan gotong royong biasa dilakukan pada saat kegiatan kerja bakti, dan pemindahan rumah.

Dengan adanya berbagai hal kegiatan baik bersifat umum maupun pribadi, menjadikan masyarakat Tolaki memiliki rasa tanggung jawab besar dalam melaksanakan kegiatan yang berhubungan dengan kepentingan umum ataupun kepentingan individu.

Keempat, budaya sopan santun (meiro'u). Bagi masyarakat Tolaki budaya sopan santun (meiro'u) merupakan unsur penting dalam kehidupan bersosialisasi sehari-hari, karenadengan menunjukan sifat santunlah seseorang dapat dihargai, disenangi dan dihormati dengan keberadaannya sebagai makhluk sosial dimanapun tempat ia berada.

Dalam kehidupan bersosialisasi antar sesama manusia sangat penting menjaga norma atau etika dalam melakukan hubungan dengan orang lain, sehingga masyarakat Tolaki menjunjung tinggi budaya sopan santun (meiro'u) agar dapat memberikan manfaat atau pengaruh yang baik terhadap diri sendiri maupun orang lain.

Budaya sopan santun (meiro'u) dalam kehidupan orang Tolaki tertuang dengan apa yang disebut mombekaponapona'ako(saling hormat menghormati), dan mombekamei-meiri'ako(saling kasihmengasihi). Hafid (2008) mengemukakan bahwa menghormati orang lain memiliki status sosial yang lebih tinggi dalam kehidupan etnik Tolaki yang tercermin dalam ungkapan inggomiu.

Dalam masyarakat Tolaki, disamping nilai kepemimpinan, budaya malu (kohanu), budaya gotong royong (samaturu), dan budaya sopan santun (meiro'u) masih banyak lagi nilai budaya atau kearifan lokal yang dapat diangkat sebagai sumber pembelajaran sejarah. Setidaknya dalam masyarakat Tolaki memiliki nilai-nilai luhur yang menjadi warisan secara turun temurun dan dapat 
HISTORIA: Jurnal Program Studi Pendidikan Sejarah Volume 8 (1) 2020

ISSN 2337-4713 (E-ISSN 2442-8728)

di terapkan dalam kehidupan sehari-hari.

Nilai-nilai itulah yang semestinya diwariskan kepada peserta didik melalui pendidikan, salah satunya dalam pembelajaran sejarah.

Proses pengimplikasian materi kearifan lokal kalosara dalam pembelajaran sejarah di sekolah, langkahlangkah yang dapat dilakukan oleh guru adalah sebagai berikut.

1) guru melakukan identifikasi bentukbentuk kearifan lokal kalosara yang berasal dari berbagai sumber (naskah,dokumen, arsip, prasasti, adat istiadat, dan kebiasaan yang berlaku di masyarakat), serta berbagai informasi tentang potensi sejarah kebudayaan Tolaki sesuai dengan standar kompetensi dan kompetensi dasar yang harus dicapai.

2) hasil identifikasi tersebut kemudian dipilih mana yang sesuai dengan topik pembelajaran dan disesuaikan dengan standar kompetensi dan kompetensi dasar yang berlaku.

3) setelah dipilih materi mana yang tepat untuk tiap topik pada mata pelajaran sejarah, maka proses pembelajaran sejarah yang memuat nilai-nilai kearifan lokal kalosara dapat diaktualisasikan oleh guru bersama siswa.

4) setelah selesai penyampaian materi, guru perlu melakukan refleksi atas materi pelajaran yang telah disampaikan termaksud materi kearifan lokal kalosara yang di integrasikan atau di internalisasikan.

5) evaluasi untuk mengukur tingkat pencapaian standar kompetensi dan kompetensi dasar.

Pada saat melakukan aktualisasi pewarisan nilai-nilai kearifan lokal kalosara, diharapkan guru tidak lagi melakukan proses penyampaian pesan secara verbal dan satu arah kepada peserta didik, bahkan ketika pembelajaran menggunakan model out dor learning, aktifitas pembelajaran (kegiatan peserta didik) menjadi pusat dari kegiatan tersebut. Sehingga baik lingkungan fisik maupun sosial dapat dijadikan sebagai laboratorium sejarah dalam membangun karakter, karena dari lingkunganlah peserta didik dapat belajar sesuai dengan kenyataan.

Secara keseluruhan variasi metode yang digunakan guru masih terbatas, sehingga metode ceramah paling sering digunakan dalam menyampaikan pesan. Maka diperlukan metode yang bervariasi guna selain menumbuhkan motivasi peserta didik juga dapat memberikan kemudahan bagi peserta didik dalam memahami sebuah materi pelajaran.

Pentingnya pewarisan nilai-nilai kearifan lokal kalosara pada peserta didik ini bertujuan agar anak didik dapat mengenal dan memahami budaya yang ada disekitarnya sehingga mereka tidak akan tercerabut dengan masuknya budaya lain yang bersifat negatif. Oleh karena itu, 
sangat penting untuk mengidentifikasi atribut-atribut dari suatu nilai budaya sehingga dapat memaknai nilai-nilai yang terkandung dalam budaya tersebut.

Hasan (2005: 250), mengemukakan bahwa setiap nilai memiliki atributnya masing-masing dan satu nilai dapat dibedakan dengan nilai yang lain berdasarkan atribut yang dimilikinya sehingga memberikan arti bahwa pengajaran nilai dalam pendidikan ilmuilmu sosial haruslah dimulai dari kegiatan identifikasi atribut tersebut.

Dalam membangun karakter siswa, pendidikan merupakan cara paling efektif untuk melakukan internalisasi nilai kepada peserta didik. Sekolah dengan lembaga pendidikan lain seperti keluarga dan masyarakat berfungsi melaksanakan pewarisan nilai budaya sesuai dengan tujuan pendidikan yakni untuk membentuk manusia yang berbudaya, maka dalam proses pembelajaran diperlukan kreatifitas guru dalam mengembangkan pamaknaan nilai dari suatu budaya.

Pengembangan nilai budaya ini dimaksudkan agar guru dapat memberikan bantuan kepada peserta didik dalam mengapresiasikan setiap nilai yang telah diajarkan. Hal tersebut akan dapat tercapai dengan efektif apabila ada kerjasama antara keluarga, masyarakat, dan Sekolah dalam menginternalisasikan nilai-nilai kearifan lokal kalosara sebagai bagian sumber belajar pendidikan sejarah di Sekolah.

Nilai-nilai budaya sebagai sumber pembelajaran akan menjadi pengetahuan baru yang diterima oleh peserta didik. Hal ini akan memotivasi peserta didik dalam mengikuti pembelajaran. Sehingga kearifan lokal sebagai sumber belajar dapat menjadikan proses pembelajaran lebih mudah dan efektif.

Berdasarkan pemahaman tersebut, maka pembelajaran sejarah dapat dikatakan sebagai suatu proses kegiatan dalam mendorong dan merangsang subyek belajar untuk mendapatkan pengetahuan sejarah, serta menghayati nilai-nilai kemanusiaan, sehingga dapat membawa perubahan tingkah laku dan menumbuhkan kesadaran akan nilai-nilai dalam ilmu sejarah.

Sardiman (1994:2) mengemukakan bahwa kesadaran merupakan suatu orientasi intelektual, sikap jiwa dalam memahami keberadaan dirinya sebagai manusia, anggota masyarakat, makhluk sosial, makhluk ciptaan tuhan, serta sadar sebagai bangsa.Terdapat beragam potensi yang dapat dicapai oleh peserta didik melalui pembelajaran sejarah, salah satunya peserta didik memiliki kesadaran dan kepedulian terhadap masyarakat dan lingkungannya, melalui pemahaman terhadap nilai-nilai sejarah dan kebudayaan masyarakat.

Berdasarkan pemahaman tersebut, dalam pendidikan sejarah, transformasi 
HISTORIA: Jurnal Program Studi Pendidikan Sejarah Volume 8 (1) 2020

ISSN 2337-4713 (E-ISSN 2442-8728)

budaya bukan berarti melakukan indokrinasi nilai-nilai yang terkandung didalamnya, melainkan mengkajinya secara logis, kritis, dan analitis sehingga peserta didik mampu memecahkan masalah yang dihadapinya. Pembelajaran sejarah tentunya tidak dapat menafikan nilai-nilai yang berkembang pada masa lalu, juga tidak dapat mengabaikan masa yang akan datang. Dengan demikian pembelajaran sejarah harus mengakomodir segala kebutuhan peserta didik, baik pewarisan nilai budaya, pengembangan intelektual, serta mempersiapkan diri peserta didik untuk masa depan yang lebih baik.

\section{PENUTUP}

\section{Simpulan}

Kearifan lokal kalosara pada masyarakat Tolaki merupakan pedoman dan pengontrol perilaku dalam menciptakan lingkungan sosial yang harmonis. Kalosara hadir dalam kehidupan orang Tolaki bertujuan untuk menciptakan masyarakat yang berbudi luhur serta untuk menjaga ketentraman dan kesejahteraan bersama dalam sektor kehidupan, sehingga menjadikan kalosara sebagai fokus kebudayaan Tolaki.

Kalosara memiliki nilai-nilai yang dapat diaktualisasikan atau di internalisasikan dalam pembelajaran sejarah guna membangun karakter peserta didik antara lain: pertama, nilai kepemimpinan yang berintikan persatuan

dan kesatuan(medulu mepokoaso), kesucian dan keadilan (ate pute penao moroha), kemakmuran dan kesejahteraan (morini mbu'umbundi monapa mbu'undawaro), keserasian, keharmonisan, keamanan dan kedamaiankedua, budaya malu (kohanu), ketiga, budaya gotong royong (samaturu), dan keempat, budaya sopan santun (meiro'u) yang meliputi saling hormat menghormati (mombekapona-pona'ako), dan saling kasih mengasihi (mombekameimeiri'ako).

Pentingnya pewarisan nilai-nilai kearifan lokal kalosara pada peserta didik ini bertujuan agar anak didik dapat mengenal dan memahami budaya yang ada disekitarnya sehingga mereka tidak akan tercerabut dengan masuknya budaya lain yang bersifat negatif. Selain itu, menjadikan pembelajaran sejarah semakin menarik dan bermakna, serta dapat berfungsi sebagai alat bagi penguatan karakter anak didik untuk mempersiapkan diri dalam menghadapi tantangan masa kini dan masa yang akan datang.

Aktualisasi pendidikan nilai
kearifan lokal kalosara dalam
pembelajaran sejarah kepada peserta
didik dapat dilakukan melalui metode out
learning, karenametode ini cukup efektif
dalam rangka pewarisan nilai-nilai
kearifan lokal kalosara. Aktualisasi dapat
dikaji melalui tiga aspek yaitu aspek
kurikulum, aspek guru, dan aspek peserta


didik. Menanamkan dan memberikan pemahaman tentang nilai-nilai budaya merupakan bagian dan perencanaan kegiatan belajar mengajar yang disusun oleh guru sejarah. Pewarisan nilai-nilai kearifan lokal kalosara dapat tercapai dengan efektif apabila ada kerjasama antara lingkungan keluarga, masyarakat, dan Sekolah dalam menginternalisasikan nilai budaya tersebut sebagai bagian sumber belajar bagi pembelajaran sejarah di Sekolah.

\section{Daftar Pustaka}

Bungin, B. (2013). Metodologi penelitian sosial dan ekonomi. Jakarta: Kencana Prenada Media Grup.

Gunawan, I. (2014). Metode Penelitian Kualitatif: Teori \& Praktik. Jakarta: Bumi Aksara.

Hafid, Anwar. (November 2013). Kalosara Sebagai Instrumen Utama Dalam Kehidupan Sosial Budaya Masyarakat Tolaki Di Sulawesi Tenggara. Makalah Disajikan Dalam Prakongres Kebudayaan Indonesia di Jakarta.

Hasan, SH. (1999). Pendidikan Sejarah Untuk Membangun Manusia Baru Indonesia. Mimbar Pendidikan. Nomor 2/XVIII Tahun 1999. Bandung: University Press IKIP Bandung.

Hasan, SH. (2012). Pendidikan Sejarah Indonesia: Isu Dalam Ide Dan Pembelajaran. Bandung: Rizqi Press.

Koentdjaraningrat. (1980). Masyarakat Desa di Indonesia. Jakarta: Aksara Baru.

Lubis, Z. (2011). Evaluasi Pendidikan Nilai. Yogyakarta: Pustaka Pelajar.

Mazi, Ali. (2004). Peranan Nilai-Nilai Budaya Lokal Dalam Pelaksanaan
Pembinaan Teritorial di Sulawesi Tenggara. Kendari.

Melamba, Basrin. (2012). Sagu (Tawaro) Dan Kehidupan Etnik Tolaki di Sulawesi Tenggara. Jurnal Paramita, Vol. 24, No. 2, Juli 222-237, ISSN 0854-0039.

Melamba, Basrin. (2013). Tolaki, Sejarah, Identitas dan Kebudayaan. Yogyakarta: Lukita.

Nawawi, H. (2005). Metode Penelitian Bidang Sosial. Yogyakarta: Gadja Mada University Press.

Sardiman. (2012). Pembelajaran Sejarah Dan Pembangunan Karakter Bangsa. Dalam Pendidikan Sejarah Untuk Manusia dan Kemanusiaan: Refleksi Perjalanan Karir Akademik Prof. Dr. H. Said Hamid Hasan, MA. Jakarta: Bee Medialndonesia.

Spradley, J.P. (2007). Metode Etnografi. (terjemah). Yogyakarta: Tiara Wacana.

Supriatna, N. (2012). Ecopedagogy dan Green Curriculum dalam Pembelajaran Sejarah. Dalam Pendidikan SejarahUntuk Manusia dan Kemanusiaan: Refleksi Perjalanan Karir Akademik Prof. Dr. H. Said Hamid Hasan, MA. Jakarta: Bee Medialndonesia.

Su'ud, Muslimin. (2008). Aneka Ragam Kebudayaan Tolaki. Kendari: Universitas Halu Oleo.

Su'ud, Muslimin. (2012). Kompilasi Hukum Adat Perkawinan di Sulawesi Tenggara. Kendari: HISPISI Cabang Sultra.

Tarimana, Abdurrauf, (1993). Kebudayaan Tolaki. Jakarta: Balai Pustaka.

Tarimana, Abdurrauf, (1993). Seri Etnografi Kebudayaan Tolaki. Jakarta: Balai Pustaka. 
HISTORIA: Jurnal Program Studi Pendidikan Sejarah Volume 8 (1) 2020

ISSN 2337-4713 (E-ISSN 2442-8728)

Tondrang, Azis, (2000). Peranan Kalosara dalam Pembentukan Karakter Masyarakat Tolaki. Unaaha: Makalah dalam Rangka Musyawarah Adat I Suku Bangsa Tolaki.

Wiriaatmadja, R. (2002). Pendidikan Sejarah di Indonesia: Perspektif Lokal, Nasional, Dan Global. Bandung: Historia Utama Press.

Wagiran. (2010). Pengembangan Model Pendidikan Kearifan Lokal Di Wilayah Provinsi DIY Dalam Mendukung Perwujudan Visi Pembangunan Diy Menuju Tahun 2025 (Tahun Kedua). Penelitian. Yogyakarta: Biro Administrasi Pembangunan.

Yulianti, Ling. (2015). Pewarisan NilaiNilai Budaya Masyarakat Adat Cikondang Dalam Pembelajaran Sejarah Di Madrasah Aliyah AlHijrah. Jurnal Candrasangkala, Vol. 1, No. 1, November, ISSN 0854-3461. 
Pewarisan Nilai-Nilai Kearifan Lokal Kalosara dalam... Rispan \& Ajat Sudrajat, 61-76 